\title{
THE LAWS OF THE SEA AND THE PRINCIPLES OF REPRISAL
}

According to the Roman Corpus Juris, the sea was a res nullius or a nullius territorium by natural law. This meant that it was free from any claims of ownership, and instead belonged to all. ${ }^{1}$ However, even though much medieval law was founded on the principles of the Corpus Juris, it did not mean that actions taken at sea took place in a judicial void and by default were permissible. How actions at sea were perceived judicially is, however, a delicate question. In this chapter, I shall analyse what laws regulated behaviour at sea, and how they failed to address the issues of piracy and reprisals. These reprisals were the common manner in which to justify piracy, and they took place in a juridical grey area where the king, on an ad hoc basis and strongly influenced by foreign as well as domestic policies of the realm, decided what reprisals should be authorised by him and when. This authorisation was expressed in two types of governmentauthorized seizures: arrest and marque. An analysis of these aspects is important, for it expresses the peculiar legal status of piracy in the Middle Ages and provides a further framework for the understanding of the status of piracy in an era characterised by weak central governments.

\section{The LAW MERCHANT}

Many historians have made assumptions about the laws of the sea and how maritime, especially commercial, life was regulated. It is a matter of debate what exactly constituted the law of the sea and commercial law in regard to piracy. The fundamental problem is whether piracy constituted a special kind of crime, separate from crimes of theft and violence committed on land, or whether the place of the crime was irrelevant in regard to the law. Marsden claimed that common law was inadequate to judge cases of piracy, since the jurors were seldom witnesses to the

\footnotetext{
1 Corpus Juris Civilis, Dig. I, viii. 2: "naturali iure omnium communia sunt illa: aer, aqua profluens, et mare, et per hoc litora maris", cited in EMDP, I, 369, n. 34. Cheyette, "Sovereign," p. 53, Heller-Roazen, Enemy of All, pp. 57 and 61-62, Ward, Medieval Shipmaster, p. 9 .
} 
crime and since one often ran the risk that they were neighbours of or in some other way affiliated with the offenders. Consequently, the jurors were more likely to sympathise than to convict the indicted. Accordingly, the laws on piracy, reprisal and war were vague, and the situation at sea tended de facto to be characterised by lawlessness. ${ }^{2}$ The historians have generally organised their studies of the legal status of the sea in the early fourteenth century around two legal institutions of maritime law, that is, the merchants' law, or Lex Mercatoria which mainly dealt with commercial transactions, and the Rôles d'Oléron, which mostly was occupied with freight and the relationship between shipmaster, crew and merchants.

One of the first obstacles that one encounters when studying piracy cases in the English legal and diplomatic records is that the plaintiffs or their lawyers argued that the case should be settled according to the Law Merchant, the laws of the sea, or the laws of Oléron. These laws are evoked as a matter of fact, and no details are given as to their contents or how they should be applied. ${ }^{3}$ In The History of English Law from 1898, Pollock and Maitland wrote that from the thirteenth century the Lex Mercatoria as a law code stood apart from the common law. It was a special law for merchants and commercial transactions and therefore did not concern itself with issues which fell under criminal law. Apparently, the merchants were familiar with the general tenets of this law, and it was used during markets and fairs where the merchants assembled. Furthermore, this law was not an exclusively English law. Rather, it was a ius gentium known to merchants throughout Christendom. However, Pollock and Maitland stressed that the Law Merchant was less a law for a class of men, but rather a law for specific kinds of transactions. ${ }^{4}$ This sums up the basics of Law Merchant, but recently Robin Ward has elaborated somewhat on the contents and development of this law. He stresses that Law Merchant had developed from the Roman Corpus Juris and was international in its nature. As such, it was well suited for adjudication in maritime quarrels. Ward claims that problems between mariners which arose on board ships and between one ship and another were subject to maritime law, which in someway was related to Law Merchant (probably to the Rôles d'Oléron, even though Ward does not state this specifically). On the whole, Ward

2 Marsden, Reginald G., "The vice-admirals of the coast," English Historical Review, 22 (1907), 468.

3 See, for example, CPR 1301-1307, p. 286.

4 Pollock, F. and Maitland, F.W., The History of English Law, 2nd edn., 2 vols. (Cambridge, 1968), I, 467 . 
claims that in England very few legal decisions in maritime cases ran contrary to the precepts of common law, Law Merchant or maritime laws. ${ }^{5}$ Ward explains the connection between Law Merchant and maritime laws thus:

all types of plea could be heard including trespass, debt and contract, but not those concerning land nor serious crimes which were reserved for royal justices. The law the courts administered was derived from the customs of English and continental merchants and in the fourteenth century was still relatively unevolved. It reflected enough of the continental lex mercatoria to be acceptable to both native and foreign litigants, stood apart from common law, was specifically for mercantile transactions rather than for merchants... Although the law merchant was of such importance to merchants and appears to have had a considerable effect on the law practised in local courts, direct reference to it by name is strangely absent from borough custumals. ${ }^{6}$

While this seems to be a fairly reliable portrayal at first glance, it is actually rather problematic. First of all, at least for the thirteenth and the first part of the fourteenth century, our knowledge of local courts and their decisions concerning matters at sea is very limited. Ward in fact exacerbates the confusion by referring to a case in Bristol in 1351, where a discussion of whether a shipmaster was responsible for the actions of his crew took place. Unfortunately is not clear whether the verdict was passed in accordance with maritime law or the law of the country. Furthermore, the case was appealed, but its conclusion is unknown, which further compounds the confusion over what law was applied in local courts in quarrels involving mariners. ${ }^{7}$ Concerning piracy, at one point Ward assumes that the judgements of the English courts followed the "law and customs of Oleron and similarly the law merchant. Both were seen as species of jus gentium available across frontiers". ${ }^{8}$ However, rather puzzlingly, Ward claims elsewhere that there was a noticeable absence of the mention of piracy in the maritime laws, and he argues that felonies presumably were dealt with ashore. In other words, felonies like piracy were perceived of as not being any different to crimes on land, and they were dealt with thus. ${ }^{9}$ This contradiction admirably sums up the historiographical problem of determining how piracy was dealt with in the courts.

\footnotetext{
5 Ward, Medieval Shipmaster, p. 9.

6 Ward, Medieval Shipmaster, p. 16.

7 Ward, Medieval Shipmaster, p. 18.

8 Ward, Medieval Shipmaster, p. 16.

9 Ward, Medieval Shipmaster, p. 23.
} 


\section{THE RÔLES D'OLÉRON}

The specific problem with the laws of the sea up to at least the middle of the fourteenth century is that there really is only one known law-code on maritime matters. This law is the Rôles d'Oléron, which seem to have been accepted and followed by all mariners in Northern Europe. ${ }^{10}$ The Rôles are linguistically dated to around 1200 and were reputedly formulated by King Richard the Lionheart, ${ }^{11}$ even though the veracity of this statement is controversial and uncertain to say the least. ${ }^{12}$ Furthermore, Ward and other historians assume an origin for the law in the Mediterranean sea laws, the Lex Rhodia, and the Consolate del Mare. The earliest two extant versions of the Rôles are, however, from manuscripts from 1315 (the Liber Horn and the Liber Memorandum), and both Ward and Karl-Friedrich Krieger assume that these are copies, directly or indirectly of an Anglo-Norman original. ${ }^{13}$ However, the possibility remains that either the Rôles are not that old, or, more likely, that they were a product of the francophone maritime communities of the thirteenth century, and that over time maritime practice manifested in the twenty-four articles of the Rôles d'Oléron, thus making them more of a dynamic document of customary law. ${ }^{14}$ It is clear that from the outset the Rôles must have been primarily concerned with the wine trade, given the number of references to this in the articles of the law. The articles in the extant version also support the notion of the law not being confined to the Anglo-French Atlantic, since numerous articles refer to England, Flanders, Brittany, Normandy and Scotland and the mariners from these areas. ${ }^{15}$

In Ursprung und Wurzeln der Rôles d'Oléron, Krieger discussed why the Rôles were created and why they were named after the island of Oléron.

10 Printed in Ward, Medieval Shipmaster, pp. 183-205, The Black Book of the Admiralty, in Travers Twiss, ed., 4 vols. (London, 1965), I, 89-133, Collection des lois maritimes, in Jean Marie Pardessus, ed., 6 vols. (Paris, 1828-45), I, 323-354.

11 Runyan and Ward date the Rôles d'Oléron to around 1200 based on the language. Ward, Medieval Shipmaster, p. 20, Runyan, Timothy J., "The Rolls of Oleron and the Admiralty Court in fourteenth century England," The American Journal of Legal History, 19 (1975), 98.

12 See Frankot, Edda, Medieval Maritime Law and its Practice in the Towns of Northern Europe: A Comparison by the Example of Shipwreck, Jettison and Ship Collision (Unpublished $\mathrm{PhD}$. thesis at the University of Aberdeen, 2004), p. 20.

13 Ward, Medieval Shipmaster, pp. 20-22.

14 Krieger (and Frankot) assumes it was written down around 1286. Krieger, Ursprung, p. 71, Frankot, Medieval Maritime Law, p. 20.

15 Krieger, Ursprung, pp. 23-30. 
While Ward assumes that the Rôles were named after the island because its magistrates were presumably reputed to be reliable jurists, ${ }^{16}$ Krieger more prudently believed that the Rôles perhaps initially referred to an Aquitainian maritime association rather than specifically to the island. Furthermore, he refused to accept a royal English origin for the text, based on, amongst other things, the rather late official English royal approval of the law in 1351. Instead, Krieger assumed its creation was based on the different merchants' and mariners' guilds of northwestern Europe in the thirteenth century. Despite being under different kings, these guilds rallied together when their privileges were threatened by, for instance, taxes on the wine trade. However, whether the Rôles were first formulated by one trading community and then adopted by the others, or whether it was a collective custom created by the different communities in unison, is unknown. ${ }^{17}$ This perception of mariners and merchants banding together against royal aggression and pretentions is tempting and seems more credible than the creation of the Rôles by the English king, especially since the king was barely mentioned in them. Furthermore, it is worth noting that, in regard to maritime conflict, Krieger focused more on the AngloFrench royal conflicts than on those between the maritime communities. He essentially saw an opposition between the mariners' interests and those of the kings. This means that all conflict was handled and regulated by the kings, and that the mariners and merchants were only interested in and concerned with peaceful trade.

This is the natural consequence of the contents of the Rôles in regard to conflicts. Piracy and maritime war are simply not mentioned in the law. Instead, the Rôles were concerned with the relationship between shipmaster and crew, and between the shipmaster and the merchants who either owned or just freighted their goods on board the ships. Dorothy Gardiner assumed that this was because ordinances concerning maritime conflict were only written up in emergencies and thus were related to individual cases of conflict and were not in any way universal principles. This was because the kings lacked a permanent naval force and thus royal maritime warfare was based on the contributions of individual ports and occurred in distinctive and unique circumstances for each war. ${ }^{18}$ Thus, Krieger implicitly followed Gardiner's initial argument that kings made

\footnotetext{
16 Ward, Medieval Shipmasters, p. 24.

17 Krieger, Ursprung, pp. 112-119.

18 Gardiner, Dorothy A., "The history of belligerent rights on the high seas in the fourteenth century," The Law Quarterly Review, 48 (1932), $5^{21 .}$
} 
war and mariners sailed and traded. However, as we saw in the last chapters, mariners were more than willing to take up arms to realize personal and collective gains.

The issue of the Rôles d'Oléron's application to conflict has been further complicated by the different names of the Rôles d'Oléron in the sources and the historiography. Thus, one can find references to maritime law as rôles, ley, lois, lex, jugemens, consuetudines and costumes - all of Oléron. While these may well be different versions of the same text with minor variations, none of the existing versions deal with conflict at sea. However, some of the legal and diplomatic records which use the above-mentioned variations of the name "d'Oléron" have references to the Rôles' application during maritime war and piracy. Unfortunately, in these references, it is rather unclear what is meant. Krieger tried to deduce what the Rôles covered and what should be assumed covered by other maritime and mercantile laws called "d'Oléron", but of which we do not know the exact contents. He assumed that the Rôles should be seen as a completion of the Lex Mercatoria, but nevertheless a law apart from those dealing with reprisals. ${ }^{19}$ He thus supposed three different yet complementary sets of laws for the sea, that is, Lex Mercatoria, the Rôles d'Oléron and a set of rules concerning reprisal. On the right of reprisal, Krieger assumed that the Rôles d'Oléron was the commonly agreed law for the regulation of maritime traffic. In this regard, the letters of marque served as the realisation of outstanding legal claims. However, marque was only to be seen as a supplement to the law, which permitted the realisation of a claim in a given case. ${ }^{20}$ Thus, the rules of reprisal should be seen as the completion of the Rôles in regard to conflict and piracy jurisdiction.

The English Fasciculus de superioritate maris from $1339,{ }^{21}$ which refers to King Richard the Lionheart as the giver of the Rôles d'Oléron and the laws of reprisal in la ley Olyroun, poses a particular problem for Krieger. Contrary to the editor of the source, Pardessus, Krieger refused to accept that King Richard formulated this law. He argued that the Fasciculus should instead be viewed as part of the Hundred Years' War and there-

19 Krieger, Ursprung, p. 35.

20 "Während die Rôles d'Oléron das zwischen den am Seeverkehr Beteiligten geltende Recht feststellen, dienen die 'letters de marque' der internationalen Durchsetzung von Rechtsansprüchen.... Im Verhältnis zu den Rôles d'Oléron konnte demnach das Recht der 'marque' nur als eine Ergänzung herangezogen werden, soweit die Verwirklichung eines nach dem Seerecht festgestellten Anspruches in Frage stand." Krieger, Ursprung, p. 36 .

21 Pardessus, Collection des lois, I, 289. 
fore had nothing to do with the origin of the Rôles. It was an invention to enhance English independence from the French Crown. Krieger writes that the ley Olyroun referred to in the Fasciculus concerned the protection of the peace and justice between people sailing the English Channel and was formulated as a promise to protect shipping, to punish pirates and to assure restitution to the victims. However, as Krieger stressed, the Rôles d'Oléron was a civil law, not a criminal law. Thus, in Krieger's opinion, the origin of the Fasciculus of 1339 was rather a Gascon petition of 1331 . While Krieger assumed that the lay Olyroun was different from the Rôles d'Oléron, his view is backed up only by a mention of this in a Bayonnais petition from 1337-39, which indicates that the Bayonnais' reprisals and marque were apparently in accordance with the lay Olyroun. Krieger therefore concluded that the ley Oliroun which mentioned a direct relationship between this law and reprisals/marque, the Rôles d'Oléron and Ley de Oliroun could not be the same law. ${ }^{22}$ In support of Krieger's argument is that the conflict regulation mentioned in the Fasciculus is not covered by any of the known versions of the Rôles, and it is possible that the Bayonnais were applying a local, Gascon understanding of conflicts in general to conflict at sea (see chapter 6). In any case, Krieger and Gardiner acknowledged that reprisals were a part of the judicial maritime system and that they were congruent with the Rôles in the sense that both were commonly acknowledged institutions by the seafarers. Nonetheless, they could not be seen as a law per se, since they invariably were "international" and thus concerned the safety of the kingdoms and diplomacy rather the interests of the mariners and merchants. Ward, however, argues against the notion that reprisals should be perceived as a part of the official judicial system of maritime law. Nevertheless, he provides a good reason for why reprisals, whether legitimate or not, were a necessary recourse in maritime and commercial transactions. This recourse rested on a deficiency in Law Merchant. Ward writes:

In common law, proof of purchase in good faith merely relieved the innocent third party from the possibility of punishment for theft, and the goods had to be returned to the true owner without restoration of the purchase money. In the law merchant, with the interests of commerce in mind, the true owner had to refund the purchase price to the bona fide purchaser on the return of the stolen goods, in effect a repurchase by the owner of his own property. ${ }^{23}$

22 Krieger, Ursprung, pp. 43-46.

23 Ward, Medieval Shipmaster, pp. 16-17. 
In other words, the merchant was liable to suffer a loss because of piracy whether he won the trial or not. In order to cover his losses, he thus had to rely on other means, and the anger and frustration that this system produced must have been a powerful urge to commit reprisals and indeed to wage war amongst ports.

In the end, we must conclude with Klaus Friedland that: "In truth, the Rôles d'Oléron are essentially concerned with ship law-the security of the ship, crew and cargo. Piracy does not figure in the Rôles. Piracy only became criminalised much later when it began to be regarded as a threat to the maritime community". ${ }^{24}$ While merchants appealed to Law Merchant and maritime law for restitution, or even to some form of the Oléron law for goods stolen by pirates, quite often the actual measure which was applied was arrest and marque carried out either by the royal authorities or by the merchants and their compatriots themselves. I will now turn to an analysis of the principles of reprisal in the Middle Ages.

\section{The Principles of Reprisal}

In the legal and diplomatic records, reprisal was described by the following words in Latin: Marca, Represalice, Pignorationes, Pignora, Quemince, Cambium et Laudes and Gagium, and in French, Marque, Représailles and Laud. ${ }^{25}$ According to DuCange's Glossarium Medice et infimce latinitatis, represalium was the right to recover your belonging from a person who had taken them from you by force. Furthermore, DuCange stressed that reprisal was the power to seize goods for injustices and damages not just from a debtor from a foreign country but also from his countrymen. ${ }^{26}$

Here it is clear that reprisals could be against plunderers and debtors. DuCange also noted the synonymy between represalium and pignoratio

${ }^{24}$ Friedland, Klaus, "Maritime law and riracy: Advantages and inconveniences of shipping in the Baltic," in MacInnes et al., eds, Ships, Guns and Bibles in the North Sea and the Baltic States, c. 1350-c. 1700 (Phantassie, 2000), p. 32.

25 Mas Latrie, René de, "Du droit de marque ou droit de représailles au Moyen Âge," Bibliothèque de l'École des Chartes, $6^{\mathrm{e}}$ series, II (1866), 537.

26 "Jus recipiendi, quod cuipiam per vim ablatum fuerit" and "Auctor Breviloqui: Repræsalia est potestas pignerandi contra quemlibet de terra debitoris data creditori pro injuriis et damnis, Idem: Repræsaliæ dicuntur, quando aliquis oriundus de una terra spoliator, vel damnificatur ab alio oriundo ab alia terra, vel etiam si non debitum solverit ei; tunc enim datur potestas isti spoliator, quod ei satisfaciat contra quemlibet in terra ille, unde est spoliator vel debitor." DuCange, Glossarium medice et infimce latinitatis, 6 vols. (Paris, 1840-1846), V, 713 . 
(seizure). For instance, he referred to Philippe le Bel's initiatives in this direction. According to the French king, seizure as described above was the means by which a prince could obtain justice for a subject who had been denied his right. The prince could concede to the subject the right to take by force anything from the subject of another prince to obtain restitution for an injustice or a robbery which he had suffered. ${ }^{27}$ While the kings allowed this practice, the Church officially condemned it and threatened excommunication of those conceding reprensalias sive marchas against clergy and their goods. For instance, in 1314 the Council of Paris issued a prohibition of "Pignorationes, quas vulgaris elocutio repræsalias nominat" (pledges which in vulgar parlance are called reprisals), as it ran counter to law and natural equity. ${ }^{28}$ The word prisia (and contraprisia), which was the act of carrying out a reprisal, was defined by DuCange as an enforcement of a debt or a tax, where the officers of a lord took (temporary) custody of goods or persons. ${ }^{29}$ DuCange defined $\operatorname{marc}(h) a$ with almost the same words as pignoratio, that is, a denial of justice whereupon the prince could concede a marque to the aggrieved so that by personal means he could obtain justice. ${ }^{30}$ Interestingly, another of the synonyms for reprisals, gagium, was explained as pignus, that is, a pledge and a fidejussio. Thus, all these words in one way or another entailed taking back property illegitimately seized by another person, including cases of debt.

The main principle behind justified attacks on and seizure of property at sea was collectively called reprisals. When people were subject to piracy or any other seizure of their ships and goods (or claimed to have been the victim of such), they could resort to private action in order to recuperate their goods or cover their losses by attacks on the seizers' countrymen. The object of reprisals was to obtain compensation for injuries or losses suffered by people who could not be brought to justice. They were in principle only licensed when legal redress for various reasons could not be obtained, and they could be levied on account of injuries to the right of an individual, to obtain restitution for spoliation, for imprisonment and for outstanding debts. The reprisal levied permitted the aggrieved, by his

27 "Facultas a Principe subdito cui jus denegatum est, concessa sibi jus faciendi atque Pignori capiendi etiam per vim quicquid poterit ab alterius Principis subdito, a quo injuria affectum se vel spoliatum queritur." DuCange, Glossarium, V, 251-252.

28 DuCange, Glossarium, V, 251-252.

29 "Exactio, malatolta, jus capiendi ex subditis ea quæ domino sunt necessaria; item sub custodies manum positio, 2. Captura, Prise: item Jus reos capiendi et in carcerem conjiciendi." DuCange, Glossarium, V, 451-452.

30 DuCange, Glossarium, VI, 279-280. 
own means, to recover his goods or persons to the value of the loss he had suffered. In relation to theories of just war, reprisal permitted the taking of spoil, but this spoil was to be seen as repayment of an amount outstanding to the aggrieved and thus not as regular spoils of war. ${ }^{31}$ While in principle it seems that reprisals were only legitimate if conceded by a prince, de facto, the mariners often seemed to take matters into their own hands rather than wait for royal authorisation.

It is necessary to stress an important distinction here, namely the one between reprisal and retaliation. Today we see these two concepts as more or less synonymous, but from a legal point of view they are quite distinct. As the name suggests, reprisal is the taking back of something, normally some sort of property, unjustly taken from the person without payment. Reprisal is thus remedial and a compensation for a loss unjustly incurred. Retaliation, however, transcends the materiality of reprisal in that it is an aggressive response to a wrong suffered, whether materially or emotionally. It is at its core a vindictive infliction onto a foe of the same damage one has suffered. ${ }^{32}$ In the Oxford English Dictionary, retaliation is defined as a retributive form of justice whereby an offender's punishment resembles the offence committed in kind and degree. ${ }^{33}$ However, a core element of both reprisal and retaliation was the concept of collective liability. An illustrative example of this can be seen in Marc Bloch's La Société Féodale. In a trial at the Parlament de Paris in 1260, the knight Louis Defeux demanded compensation from the squire Thomas d'Ouzouer for having wounded him. The accused did not deny that he had wounded Louis, but he explained that he himself sometime before had been attacked by Louis' nephew. Thomas thus defended himself by stating that he had done nothing wrong since he-in accordance with the royal decrees of a period of fair warning - had waited forty days before carrying out his vengeance. Louis replied that he was not liable for the actions of his nephew, but with no luck. The court decided that the act of an individual made his relatives liable for his actions. ${ }^{34}$

Thus, the reprisal or retaliation was permitted not only against the transgressor, but also against his family, friends and associates. In this

31 Keen, Laws of War, p. 218.

32 Neff, Stephen C., War and the Laws of Nations (Cambridge, 2008), p. 123.

33 Oxford English Dictionary http://dictionary.oed.com/cgi/entry/50204656? single=1\& query_type=word\&queryword=retaliation\&first $=1 \&$ max_to_show $=10$. Accessed on 25 February 2011.

${ }^{34}$ Olim, I, 472-73, ORF, I, 56-58, Actes du Parlement, I, 38, no. 436, Bloch, Marc, La société féodale (Paris, 1994), pp. 187-188. 
regard, the maritime war between the Anglo-Bayonnais and the Normans was retaliatory. However, there was a difference between war and reprisals/retaliation. Keen presents the difference thus:

Theoretically justice was claimed for such reprisals, on the ground that injured and innocent both were subject to the judge who had refused redress, and so all were party to the crime. The case with feudal war was a little different. It was levied for the same end, to protect the right of an injured individual, but for defiance only entitled the defier to take revenge on his opponent personally, or on his relatives and direct dependents. ${ }^{35}$

Reprisals were thus not arbitrary or anarchic but rather followed a sort of regulated custom or convention for conflict and dispute settlement. For maritime offences, the procedure was usually the following: If a merchant or a shipmaster was attacked and plundered by foreign mariners, he would first complain locally in the nearest port, as for instance Bartholomew de Welle did. If nothing came of this, or if the accused could not be located and apprehended, the victim would appeal to his king to gain restitution by having him advance the case to the foreign king and his court. If the victim's king — after adequate inquiries in the case-chose to plead it with the foreign king (or possibly port authorities) and demand restitution for the aggrieved, the latter would consider the case, hold his own inquiries, and report back to the victim's king. Often a case like this could take years if not decades before any restitution or final refusal had been made, and stalling the cases seems to have been the preferred royal tactic in these matters. In time, the king of the aggrieved would often threaten to and ultimately carry out arrest of the opposing king's merchants' goods in his ports up to the lost value, perhaps augmented by the expenses that the victim had suffered by pursuing the case (but no more), to be held until the foreign king made restitution. Alternatively, the aggrieved could appeal for a letter of marque and if his plea was accepted, the letter would authorise him personally or with the help of royal officers, to confiscate goods from the foreign king's merchants and mariners. However, even the concession of arrest or letters of marque could take years, and all other means of restitution and recovery of the lost goods had to be tried before reprisals were authorised. If arrest was initiated by the royal officers, the arrested goods were put under custody of the royal agents until a final settlement had been reached, either by the foreign ruler granting restitution or by the victim's ruler deciding to deliver the arrested goods to the

35 Keen, Laws of War, p. 230. 
aggrieved and then consider the case closed. What could happen, however, was that the foreign ruler would issue counter-reprisals and arrests for his innocent subjects, to the effect of a drawn-out series of arrests and counter-arrest until some larger settlement where all outstanding claims and counter-claims were solved, or possibly by permitting the victims free process in the pirate's homeland. The historians usually claim that only arrest of goods was permitted, not people, and that the use of force was in theory prohibited, ${ }^{36}$ yet how arrests and reprisals were expected to happen in practice without the application of some sort of force is unclear. Indeed, contrary to the principles presented by the historians, the English "keeper of documents", Ellis Joneston, asserted that recourse to the detaining of people was a recognized and acceptable (though lamentable) practice in reprisal and marque procedures. ${ }^{37}$ The same is amply present in the complaints over piracy where the arrest (actually hostage-taking to guarantee restitution) was a common practice. ${ }^{38}$

It was only the ruler in his capacity as prince with no superior who could issue arrest and letters of marque, since the laws which permitted reprisals were the same as those permitting public war, namely the ius divinum and ius gentium, which were the only war-actions permitting the taking of spoils. Some mariners and merchants like the Normans, the Portsmen or the Bayonnais found this unacceptable and thus took matters into their own hands, as is exemplified in 1292-93. Such a reprisal over a perceived wrong would most often cause the innocent compatriots of the alleged pirates/the accused to desire reprisal of their own against the initial reprisal-takers or their compatriots, and events could quickly escalate if the kings or other higher authorities did not intervene to mediate in the conflict. So, essentially, reprisal was based on group liability and semi-private revenge, and the transition from reprisal to retaliation was a sliding one. ${ }^{39}$

36 Timbal, Pierre-Clément, "Les lettres de marque dans le droit de la France médiévale," Recueils de la Société Jean Bodin, X, L’Étranger, vol. II (Bruxelles, 1958), 130-131. See also the procedure applied in the case of Bartholomew de Welle in chapter 2.

37 “corporum et bonorum arrestaciones, que mark' in terra Vasconie vulgariter nominantur.” EMDP, I, pp. 365-366.

38 See, for instance, EMDP, I, 398-401 and Foedera 1307-1327, pp. 89-92.

39 For the reprisal procedure, see Mas Latrie, "Droit de marque," pp. 530-31 and 540, Chavarot, Marie-Claire, "La pratique des lettres de marque d'après les arrêts du parlement (XIII _-début XVe siècle)," Bibliothèque de l'École des chartes, 149 (1991), 79-86, Gardiner, "Belligerent rights," pp. 538-539, Keen, Laws of War, pp. 219-222. 
While this model in principle looks straightforward, numerous problems were de facto the result of it. The relationship between reprisals and war in particular put a strain on the relationship of the rulers. These small-scale injuries and private actions constituted a rather peculiar problem for the kings, in that they were too small to call for military action on the part of the rulers, but on the other hand they were big enough that they could not be ignored. In a sense, reprisal was akin to war and police actions, only it was carried out by private persons and not the officers of the king. ${ }^{40}$ Thus, "Reprisals were... really an exercise of domestic law enforcement albeit delegated law enforcement_-rather than a resort to war properly speaking". ${ }^{41}$

Since piracy entailed the killing and brutalisation of the victims, it must have engendered strong feelings of animosity towards the pirates, as well as their countrymen, who might justly be seen as accomplices. In this light, reprisal functioned as a controlled form of vengeance justified as restitution and debt recovery. Indeed, the language of the legal and diplomatic records seems to down-play what was at stake by describing it in terms akin to economic transactions.

The private actions of reprisals constituted a juridical as well as diplomatic problem in the late Middle Ages. In practice, the principle of collective liability meant that one offence could spread out to engulf a whole community, since actions against the innocent countrymen of the pirates by the aggrieved in turn called for counter-reprisals. ${ }^{42}$ Thus, the risk of an escalation from reciprocal reprisal to outright war or at least diplomatic crisis for the kings was always latent.

However, reprisals also benefited the rulers. Apart from the limitation of private retaliation and reprisal, Emily Sohmer Tai argues, on the basis of maritime politics in the Mediterranean in the fourteenth and fifteenth centuries, that it was a conflict-reducing medium. On the one hand, the princes wanted to acquire justice for their subjects, but on the other hand, they did not want to go to war for single cases of maritime theft. It was therefore better for the princes to control the means of private restitution than not to interfere at all, since the aggrieved might be tempted to have recourse to private acts of reprisal and unauthorised acts of confiscation and violence, which could lead to an escalation of conflict and

\footnotetext{
40 Neff, War, pp. 50 and 76.

41 Neff, War, p. 80.

42 Keen, Laws of War, pp. 213-214.
} 
drag the princes into the struggle anyway. Tai calls this a safety valve on an often combustible maritime situation. However, the control of reprisals also had another benefit for rulers. By controlling the right to decide what was legitimate reprisal and when it could be carried out, the princes affirmed their control over vessels and individuals and permitted them to define what constituted crimes and what was justified reprisal. Thus, on the one hand the prince appeared as the defender of their subjects' rights, and on the other he reinforced his position as the supreme power of the realm with a sovereign right to define right and wrong. ${ }^{43} \mathrm{~A}$ similar view is advanced by the legal historian, Alfred Rubin, who states that the issuing of letters of marque and reprisal was not an attempt to control or curb piracy but rather to control and limit private legal remedies without having to commit royal military resources to the dispute. Rubin argued that by granting right to reprisal, the rulers seemed to give in to their subjects' pleas but in fact strengthened their power over their subjects by limiting and controlling their use of private force. ${ }^{44}$ However, as we shall see in next chapter, this safety-valve could also have the opposite effect, namely to question or challenge the king's right to jurisdiction over the sea.

\section{Arrest and Seizure}

While Edward I promised foreign merchants in 1303 in the Carta Mercatoria that they would be exempt from prise and arrest, ${ }^{45}$ the kings often had recourse to this measure. I shall begin with the king's order for arrest of foreigners' goods in their ports, since this is the first step in the reprisal and restitution procedure. The order of arrest was usually issued to royal English officers in one or more specific ports where fellow-countrymen of the pirates plied their trade. However, in wartime the kings would issue a general order of arrest of the enemy's subjects' goods in all his ports, a procedure the English used against the French and especially against the Scots and the Flemings in the period from 1280 to $1330 .{ }^{46}$ Restitution for individual victims of piracy was most often only addressed to a select few ports (even though sometimes the kings would bundle complaints together, and threaten and sometimes carry out a general arrest).

43 Tai, "Marking Water".

44 Rubin, Law of Piracy, p. 34.

45 Early English Customs System, p. 261 ("nullam prisam vel arrestacionem seu dilacionem occasione prise").

46 For instance, Foedera $1307-1327$, p. 562. 
In France, the same system was applied, but as the reprisal in the form of arrests and letters of marque was a tiresome and sometimes fruitless procedure, starting with Philippe le Bel in the fourteenth century, a procedure of mandatory taxes on foreign merchants trading in France was created. However, it seems exclusively to have been used in southern France in dealings with Italian merchants. Furthermore, while this tax was levied as a surety to pay for incidents of theft as well as debt evasion and other "financial" crimes committed by Italians, the levying of the tax was dependent on treaties between France and the foreign power in question. Thus, it was not a universal French royal policy but rather something applied in relation to specific groups or polities. ${ }^{47}$

One example of a French maritime arrest dates to 1322, when the Parlement de Paris ordered a reprisal in the form of arrest of goods of Spanish merchants from La Coruña. The order read accordingly:

Order to the bailiff of Caux to arrest the person and the goods of inhabitants of La Coruña which he finds in his jurisdiction in reprisal of the crimes of the inhabitants of the said town as they have provided sanctuary for robbers and murderers guilty of having attacked near Belle-île a ship charged with wines from Bordeaux which belongs to merchants from Dieppe. ${ }^{48}$

An English example of an arrest order is comprised of the proceedings in the restitution for English ships taken and plundered by the French admiral, Berenger Blanc, and his Calaisien mariners in 1315 and 1316 during the French war against Flanders. Since England and France were at peace in this period, and indeed collaborated in their struggles against the Flemings and the Scots, negotiations over the restitution of these goods commenced. Despite the state of peace between the two kingdoms, in 1318 and 1319 the English proceeded to counter-prises (that is, arrests) against French merchants, specifically of Rouen and Amiens, by confiscating their goods in London, Norfolk, Suffolk and Southampton up to a specific amount in order to obtain restitution for the English merchants. In this case, on several occasions Philippe V wrote to Edward to have him postpone or cancel the declared reprisal (marcham seu contraprisiam), often

47 Chavarot, "Lettres de marque," p. 87.

48 "Mandement au bailli de Caux d'arrêter la personne et les biens des habitants de La Corogne (de Croigne) qu'il trouvera dans le ressort de sa juridiction, en représailles des méfaits des habitants de la dite ville qui avaient donné asile à des voleurs et meurtriers, lesquels avaient attaqué près de "Bel-lille" un vaisseau chargé de vins de Bordeaux, appartenant à des marchands de Dieppe." Actes du Parlement, II, no. 6916, p. 474. 
with success. ${ }^{49}$ These proceedings were not a cause of enmity between England and France, and while the case did not please either of the monarchs and the negotiations and restitution were a complicated affair, no severe damage to the relationship seems to have come out of it. However, this did not mean that the tone could not be harsh at times. On 15 October 1311, Philippe le Bel complained about a piracy committed against Rochelais merchants. Philippe le Bel informed Edward that he had refused to issue a letter of marque (marcham ... concedere) to the Rochelais, but the mere mentioning of this constituted a veiled threat that this would be Philippe's next step if restitution was not obtained. In 1313, restitution was obtained, which was remarkably fast for the period, ${ }^{50}$ but it should be noted that Philippe's letter was sent a few months after the breakdown of the Anglo-French negotiations of Périgueux (12 January-2 June 1311) over Gascon disputes, ${ }^{51}$ and the risk of further French involvement in Gascony may have been the cause for the swift closure of the case.

A person could, however, obtain immunity from arrest and marque by having the king issue a letter of safe conduct. For instance, in 1314 Edward II granted a letter of safe-conduct for life in the Duchy of Aquitaine to Pierre de la Posterle of Oléron. This meant that his goods were free from arrest or marque except for his own debts or for those where he was a guarantor. ${ }^{52}$

\section{Debt}

These arrests were not confined to the monarchs and their officers, however, and it seems as if arrest for debts was one of the motives for having recourse to piracy and maritime war. Thus, in the peace treaties between Bayonne and the Cinque Ports, and Bayonne and Great Yarmouth from 1277 (renewed in 1310), one of the clauses was to regulate the recovery of debt. The clause states that

49 For the whole case, see: CPR 1313-1317, pp. 501-502, 545-546, 571-572, CCR 1313-1318, pp. 291, 341, 345-346 and 475-476, CCR 1318-1323, pp. 13-14, 52, 496 and 692. Foedera $1273^{-}$ 1307, p. 961, Foedera 1307-1327, pp. 272, 279, 280, 281, 292, 342, 350, 373, 455, 502-3 and 517. Champollion, II, 71-73. Calendar of Chancery Warrants 1244-1326, pp. 427-428. For other examples of arrests and counter-arrests, see TNA SC 8/258/12890A and TNA C 47/28/1.

50 Foedera 1307-1327, pp. 146 and 149, CCR 1307-1313, pp. 445, 486-487 and 565.

51 Chaplais, Pierre, "Règlement des conflits internationaux franco-anglais au XIV siècle," Le Moyen Âge, vol. 57 (1951), pp. 282-283.

52 EMDP, I, 387-388. 
if a man from either party owes debts to persons of the other party, if the debt is know it must be paid as soon as possible or the debtor shall be denied company of either of the parties, and he shall be denied entrance in towns of either party as well as ships, galleys or vessels belonging to either party until the debt is paid. And for unknown debts, let either party make justice as it is due. ${ }^{53}$

In the treaty between Bayonne and the Normans from 1282, it was stressed that: "In turn, should dispute arise again because arrests which are called marches, we command that no master or mariners arrest anything of the countrymen of the debtor because of debt or offence of the principal arrest if the debtor or his fidejussor can be found". ${ }^{4}$

Here the words of arrest and marque were used in direct relation to the issue of outstanding debts and piracies and war between these marines.

Pollock and Maitland's study of English medieval law expresses a procedure of suits and collection of debts which resembles the arrest and reprisal procedure. Like the cases of arrest, the issue was that the lender or sellers had parted with property and demanded a return through legal action. Furthermore, as in arrest cases, the plaintiff not only demanded restitution for the sum lost but in addition damages for unjust detention. ${ }^{55}$ This relationship between debt and arrest is shown in various English sources concerning Law Merchant. For instance, in 1310 the sheriff of Yorkshire arrested goods of merchants of Groningen for outstanding debts to an English merchant. ${ }^{56}$ In his studies of the medieval shipmaster, Ward has shown that there was a widespread use of credit in maritime commercial transactions and that several ingenious methods were employed to mask

53 "tutz les hommes qi sont des parties e deyvent dette as autres, si la dette est conue, soit paie tant tost si le deitur ad dount paier la dette, et sil ne ad dont paier, adonk ne soit le dettur resceu en compaignie ne en commune en nule des villes que sont d'une part ou d'autre, ne en neef, ne en galeie, ne en vessel, si la que la dette soit paie; et pur les dettes que ne sont pas conues, que face chescon de les parties le foer ou droit que devera faire." Printed in Goyheneche, Bayonne, p. 534.

54 "Rursum quia ex arrestacionibus que vocantur marches quandoque dissencionis occasio reviviscit, ordinamus quod ad instantiam aliquorum magistrorum vel nautarum nullus ipsorum arrestetur nisi pro debito vel delicto [quo-Chaplais] de arrestatus principalis debitor vel fidejussor existat." TNA C 47/32/22/2. See also EMDP I, 387 .

55 Pollock and Maitland, English Law, pp. 212-216.

56 Select Cases Concerning the Law Merchant A.D. 1239-1633, ed. Hubert Hall (London, 1903), pp. 81-83. This collection of sources contains several accounts of debt and arrest, see, for instance, pp. 7-9, 11-12, 72-73, 73-76, 81-83, 83-85, 90-93 and 96-98. Most of these cases are somewhat ambiguous as to whether the arrest was justified. The fact remains, though, that the arrests by royal officers were often carried out for the recovery of debts. 
interest, which it was illegal to demand in the Middle Ages, ${ }^{57}$ but which might have been a source of strife among the mariners nevertheless.

However, cases of robbery or any type of violent acquisition, which arguably is at the core of the unjust detention through piracy, were not treated by Pollock and Maitland. They only considered debt and arrest in a civil and strictly commercial context. Nevertheless, French historians have recently explored this aspect. In her studies of marque in France in the thirteenth and fourteenth centuries, Marie-Claire Chavarot has pointed out that the victim of a theft or the creditor of an unpaid debt could be obliged to use violence to recover his money, not only from the delinquent himself but also from his countrymen. ${ }^{58}$ An early case of French arrest was in 1263, when a Rouenais merchant was accorded an arrest of goods belonging to Germans because the king of Germany had an outstanding debt to him; another case occurred in 1270, when Robert d'Artois was accorded arrest against the commune of Saint-Valéry for a debt. In relation to piracy, however, the case of Montpelliérain merchants who were plundered by Genovese pirates is especially illustrative. These merchants were accorded a marque against the Genovese merchants in Nîmes, since that town had an especially large population of Genovese merchants. Thus, the concept of collective liability was invoked, and innocent Genovese merchants were to answer for crimes committed by their countrymen. Furthermore, the Montpelliérains did not have to take to the sea to obtain restitution. ${ }^{59}$ Indeed, Chavarot stresses that the justification for the issuing of a marque was a tort unjustly committed by a foreigner. This tort could be a theft, plunder, non-payment of a debt, a promise which was not kept or the deprivation of a right. ${ }^{60}$

Julie Claustre's studies of debts in the later Middle Ages further illuminates how debt could bring enmity between people. Claustre demonstrates that the use of debt was by no means confined to merchants and the upper levels of society. Rather, credit and loan-giving/-taking was

57 Ward, Medieval Shipmaster, pp. 69-70.

58 Chavarot, "Lettres de marque," pp. 53-54, "la victime d'un vol ou le créancier impayé pouvait être entraîné à reprendre son dû sur les biens des compatriotes du déclinquent par les moyens les plus violents et irréguliers."

59 Chavarot, "Lettres de marque," pp. 56-59.

60 Chavarot, "Lettres de marque," p. 79, "Le point de depart [for a marque] est un tort injustement cause par un étranger, quelle que soit la nature de ce tort, vol, pillage, non paiement d'une dette, promesse non tenue ou encore privation d'un droit." 
present throughout all layers of society. ${ }^{61}$ Debt and credit most often took place within familial or professional relations and was governed by the logic of reciprocity and solidarity. Accordingly, she states that debt was a "convention", meaning that it was an arrangement or an understanding between persons already connected through other relationships. It was in no way a formal transaction between a person and a credit institution, but was instead a transaction which relied on already existing bonds of acquaintance. However, this initially peaceful understanding also had a darker side to it, namely that it established a relationship of dominance and dependency, expressed in legal terms as an "obligation" (obligatio). Obligatio in the Middle Ages defined less a kind of contract than a method of executing a contract. The medieval expression for debt thus insisted on the restraining bond which it imposed on the debtor in relation to the creditor, rather than on the amount owed, that is, the object of the contract. ${ }^{62}$ In other words, it gave the creditor a measure of power over the debtor, and made the debtor a dependent of the creditor. This dependency and the troubles of outstanding debts and the disruption of the hitherto reigning relationships of power amongst, for instance, neighbours in Paris led to festering anger, desperation and hatred. This is found in numerous cases of aggression and murder in fourteenth-century France perpetrated either by the creditor or the debtor (for instance, for gambling debts). In a society devoid of the impersonal bonds of modern credit institutions, the pursuit of an outstanding debt appeared as a means to humiliate an enemy, which in turn could result in the debtor seeking vengeance for this humiliation. ${ }^{63}$ The fundamental cause for this development was the absence of unified credit institutions and financial transactions, like loan-giving, which were at the same time diffuse, multilateral and devoid of the impersonal character which is present in modern society with a institutionalised credit market. Since these institutions were absent, the loan rested in terms of security on the personal relationship between the creditor and the debtor. Consequently, the relationship of credit was also an emotional one filled with social and cultural significations which went beyond a mere relationship of economic dominance. It entered into the

61 Claustre, Julie, "La dette, la haine et la force: les débuts de la prison pour dette à la fin du Moyen Âge," Revue Historique, 644 (2007), 799.

62 Claustre, "La dette," pp. 800-802.

63 Claustre, "La dette," pp. 802-809. For an example, see Confession et jugements de criminels au Parlement de Paris (1319-1350), eds Monique Langlois and Yvonne Lanhers (Paris, 1971), pp. 111-114. 
definition of a social identity which was publicly constructed and reconstructed by conversations, rumours, reputation, and fama, which in turn called for the use of force for its defence. ${ }^{64}$ Indeed, a creditor of outstanding debts which were not forthcoming could and would stigmatise the debtor as a thief. This permitted the creditor to apply private force to obtain the amount due if no public officers could be persuaded to exercise it for him..$^{65}$

It seems more than likely that at least some of the piracy cases, as well as the maritime wars, had started with debts which the debtor perhaps had tried to evade or which the creditor, his kinsmen or fellow citizens decided to claim by private arrest, honestly or fraudulently. This seems to be the essence of at least some of the cases of reprisal, namely taking back one's due, but needless to say, and as was already apparent in the medieval as well as our understanding of the word "reprisal", this must often have led to conflict, in court or by violence. No one could be expected to hand over goods for outstanding debts to a private third party who claimed to exact the debt on behalf of their fellow citizen. However, in legal terms, it still meant that what was described in the sources as lawful debt collection or reprisal was tantamount to theft and robbery.

\section{Henry de Oreford of Ipswich and the Procedure of Restitution}

Medieval kings were very reluctant to grant letters of marque. Instead they preferred arrest carried out by public officers after careful inquiries into the case. It seems as if these letters of marque, at least in the thirteenth and first quarter of the fourteenth centuries, were very much an instance of last resort, entered into only reluctantly when all other methods had failed. The reason for this was the obvious and almost inevitable series of reprisals between the merchants and mariners of the realms. An illustrative example of this course is the case of Henry de Oreford, merchant of Ipswich. In 1305 at the latest, Henry's ship, La Lyon de Herewyk, was attacked by Breton pirates (malefactores) from Le Conquet, presumably on the Island of Quéménès ("in insula de Kenevoys in Britannia"). The Bretons violently took the ship, valued at $£ 200$ sterling, and its cargo, also valued at £2oo sterling, and imprisoned the crew for a long time, all to

64 On fama, see Akehurst, F.R.P. "Good name, reputation, and notoriety in French customary law," in T. Fenster and D.L. Smail, eds, Fama-The Politics of Talk Reputation in Medieval Europe (London, 2003), pp. 75-94.

65 Claustre, "La dette," pp. 809-811. 
the severe destitution of Henry. Furthermore, this occurred at a time of peace, meaning that the piracy probably happened sometime between 1303 and $1305 .{ }^{66}$ In 1312, Edward II wrote to his seneschal of Gascony stating the above-mentioned and adding that the duke of Brittany had freed the mariners but had refused to do Henry justice. Edward continued that when he had ascended the throne, he had ordered the seneschals of Gascony, John of Hastings and Guy Ferrers, that they should begin legal proceedings against the Bretons and (presumably) arrest their goods if they came to the duchy in order to do justice to Henry de Oreford: "completely in accordance with the legal statements of the said regions". ${ }^{67}$ Despite several letters to the duke of Brittany, Arthur II, demanding restitution, nothing had happened; the king now ordered the arrest of all Breton merchants' goods in the Duchy of Gascony. Apparently, no reply came from the duke, and Edward ordered John Salmon, bishop of Norwich in the county of Richmond (a fief under the duke's uncle, Jean), and two royal officers that if the Bretons and their goods came to Gascony, they were to summon them, hold court and to do speedy justice to Henry. ${ }^{68}$

In a letter from 12 September 1317, from Edward II to the duke of Brittany, now Jean III, we find the continuation of the case. Apparently, the arrested goods of the Breton merchants were released by the commissioners without any restitution to Henry, but Henry seems to have been allowed to try the case at a court in Brittany. Nothing came of this, however; rather, Henry was beaten and grievously wounded by the duke's men while prosecuting the case there. Therefore Edward II ordered the new seneschal of Gascony, Gilbert Pecche, to make a new examination of the case. This clearly proved the aggrieved status of Henry, and Pecche and his council granted Henry (at his request) a letter of marque (marcham, lettre de marche) against the Bretons and their goods until Henry could be satisfied to the amount of £186o sterling (sic!)— that is, the initial loss plus compensation for further damages to Henry. However, at the intervention of the Breton duke's proctor, Pecche suspended the execution of the letter of marque. This was a mistake, however, for instead of granting restitution to Henry, the duke tried to have Henry's suit annulled by presenting

66 The whole case is documented in: $R G$, IV, no. 689, pp. 193-194 and $C C R$ 1313-1318, pp. 566-567 and 617. TNA SC 8/241/12028, SC 8/262/13085, SC 8/132/6564, SC 8/132/6566, TNA C $61 / 32 / 29$.

67 "complementum secundum foros et consuetudines parcium predictarum," $R G$, IV, no. 689 , p. 194.

$68 R G$, IV, no. 689 , p. 194. 
it at the Parlement de Paris, thereby circumventing and undermining Edward's judicial authority by appealing to his liege lord for Gascony. ${ }^{69}$ Now, Edward wrote the duke that before he reissued the letter of marque to Henry, he would for one (last?) time ask the duke to grant Henry restitution as Edward preferred the matter to be solved "in a friendly manner rather than that his damages should be levied from non-consenting parties (ab invitis), as is usual in such cases". ${ }^{70}$ The duke was given until 30 November to certify that he had undertaken the restitution, or else the marque would be reactivated.

In a memorandum from 1318, it seems that Henry had finally obtained a partial restitution. Here it is stated that the letter of marque (marchia quedam) was awarded to Henry and that apparently a Reymund del Mays was appointed - with the consent of the Bretons and Henry - to levy the marque (that is, Henry would not enforce it himself) of the £1860 sterling. The memorandum stated that Reymund had received from the goods of Bretons in Bordeaux 234 "livres de petits tournois noirs", ${ }^{71}$ which he had paid to Henry without Pecche or his men having received any of this. This was confirmed by the chancellor, the bishop of Winchester. However, in December 1318, the marque was again activated as Henry still had not been provided full restitution. ${ }^{72}$ This is the last that we hear of this case, which in 1318 had been going for at least thirteen years. It also seems as if the Bretons, with or without the duke's consent, in the end accepted to grant restitution to Henry. This example shows how difficult it was to get restitution through the judiciary system, the hazards of pursuing the case abroad (the beating of Henry in Brittany) and the nature of the letter of marque, which, at least in the memorandum, appears to have been conceived of as an act carried out by a "neutral" middleman and confirmed by royal authorities. It also shows the confiscatory nature of the marque, even though the letter to the duke from 1317 seems to imply that Henry could carry out the marque personally and with force. Moreover, the case shows how hard it was to be granted a letter of marque and how easily it could be revoked. Furthermore, the statement that Edward preferred it to

69 For appeal to the French kings, see Cheyette, Frederic L., "The royal safeguard in medieval France" in J.R. Strayer and D.E. Queller, eds, Post Scripta: Essays on Medieval Law and the Emergence of the European State in Honor of Gaines Post (Rome, 1972), p. 650.

${ }^{70}$ CCR $1313-1318$, pp. 566-567.

${ }^{71}$ According to TNA C $47 / 27 / 7$, there were ten livres de petits tournois noirs per £1 sterling. Thus, Henry was only recompensed of $£_{23.4}$ sterling, a far cry from the claim of $£ 1860$ sterling.

72 CCR 1313-1318, p. 617, TNA C 61/32/29. 
be carried out in a friendly manner refers to the risk of a chain of reprisals which, in general, no ruler had any interest in. Finally, it shows the dirty tricks applied in suits like this one, as the duke of Brittany tried to appeal to the Parlement de Paris which often judged in favour of parties friendly to the French king.

The case of the piracy against Henry de Oreford is therefore an excellent example of the weakness of the procedure. It explains why some merchants and mariners seem to have preferred to take matters in their own hands, not least because the rigidness and uncertainty of the procedure could mean the destitution and poverty of an otherwise well-off merchant.

\section{REPRISALS AND LETTERS OF MARQUE}

The coincidence between the words used for letters of marque and those for the march, that is, a region with no clear jurisdiction, or rather overlapping jurisdictions characterised by frequent recourse to private actions of reprisals and retaliation, has led some historians to see the etymology of the expression, letter of marque, as a signifier of the sea being a marcher area (see chapter 6). In the nineteenth century, in Glossaire nautique Augustin Jal assumed that the "marque" was directly connected to the meaning of march as a border or a frontier, ${ }^{73}$ and that letters of marque consequently should be read as frontier letters, that is, commissions for actions of private justice on the fluid borders of the medieval kingdoms.

This notion was supported by René de Mas Latrie. He argued that the reprisal system was Germanic in origin, since it was unknown to Roman Law. Indeed, the only mentions in Roman Law of reprisal was the prohibition of this practice. Thus, in the fifth century, with the breakdown of the Western Roman Empire and the advent of the Germanic kingdoms, a fundamental change in the law system occurred. Mas Latrie argued that the Germanic tribes' coherence was based in particular on family and tribal solidarity, which ran counter to the Roman Empire's formal focus on juridical universalism. As Mas Latrie put it: "The spirit of collective liability went well beyond [the family] amongst these people. All the members of a hundred, or rather of the same march, were held responsible

73 Jal, Glossaire Nautique, p. 925. 
for an offence or a crime committed by one of their commarchati". ${ }^{74}$ Consequently, family members were obliged to defend their relatives, and collective liability in reprisals was the cornerstone of the system. In practice, however, this act could only lead to escalations of conflicts and in principle exacerbate the problem rather than alleviate it. Around the eleventh century, the Mediterranean cities were the first to put formal limitations on reprisals by having governments regulate it by letters of reprisal and marque. ${ }^{75}$ Thus, Mas Latrie concluded that there was a direct connection between the march and the right to reprisals expressed in letters of marque.

However, in the twentieth century this connection between "marque" and march area has been refuted by Pierre-Clément Timbal and Chavarot. They questioned the etymological connection between the words and considered it a mere coincidence that many of these reprisals took place in frontier areas. Timbal argued that "marque" came from marcare or marchiare, used in the same sense as pignorare in the medieval texts. ${ }^{76}$ Chavarot stressed the synonymy with pignus, that is, pledge and an economic transaction, but she refrained from explaining the word's origin. ${ }^{77}$

In effect, what Timbal and Chavarot argued was that no linguistic connection could be made between marque and march. Instead, they referred to the meaning of one of marca's synonyms, pignus and pignoratio, which were well known concepts in Roman property law. However, while marca presupposes seizure by way of reprisal, pignoratio, but especially pignus, are more abstract terms that simply denote distraint for non-payment of goods or for a service rendered and pledge of valuables. The words say nothing about the way in which this money or these goods were recovered contrary to marca, which presuppose a direct action on part of the aggrieved or the "creditor" to obtain his due. This further seems to have negated the direct connection to Germanic customary law. However, while pignoratio indeed seems to have expanded the meaning of marque considerably, the coincidence that marque was applied especially in marcher areas is still left unexplained.

74 “L'esprit de la responsabilité commune s'étendait encore bien plus loin chez ces peoples. Ainsi tous les membres d'une même centaine, ou plutôt d'une même marche, commarchati, étaient tenus du délit ou du crime commis par l'un d'eux." Mas Latrie, "Droit de marque," p. 534 .

75 Mas Latrie, "Droit de marque," p. 537.

76 Timbal, "Lettres de marque," pp. 113-114.

77 Chavarot, "Lettres de marque," p. $5^{2}$. 
Thus, while "letters of marque" and "march" etymologically seem to have different origins and indeed did not presuppose one another, they were related as a practice. In the march, private action to obtain restitution was permitted, something which the letters of marque conceded by princes also allowed under special circumstances. ${ }^{78}$ So, in both cases, the heart of the matter was restitution and satisfaction legally obtained by private persons and by private means. As we shall see in the next chapter, the method for settling conflicts at sea was the method applied in the marches, that is, by arbitration and negotiation rather than strict judicial action on the part of a prince.

I therefore argue that while in its various forms the expression "marque" and "march" did not initially seem to be etymologically related, the letter of marque fitted rather well with the procedure for pursuing claims by private means (as well as with governmental support in some cases) against the offender, as well as his compatriots, in a march.

If the procedure of arrests failed, the ultimate resort was, as we saw with Henry de Oreford, to issue a letter of marque. Chavarot's analysis of the development of the letter of marque in the Middle Ages in the documents of the Parlement de Paris shows that it — as a codified governmental measure for restitution of goods - spread progressively in the thirteenth century from the Mediterranean cities in Italy and Aragon to France. From the last third of the thirteenth century, the concept of marque was clearly present in the decisions of the Parlement de Paris, even though the term itself was not used until later. In the thirteenth century, the Parlement de Paris (but also the bailiffs and seneschals) ordered reprisals akin to marque, but the first case where the term "marque" was used was not until the case mentioned above between the Montpelliérains and the Genovese in $1308 .{ }^{79}$ The marque cases in the Parlement de Paris are dominated almost exclusively by Mediterranean cases. This seems to signify that the approach to matters in northern Europe followed another line, most probably because the English kings were the French kings' vassals for the Duchy of Gascony. Consequently, the French kings considered the quarrels that could result in reprisals and marque to be domestic affairs where they were the ultimate judges, whereas the cases with the Italians and the Aragonese were clearly of an international character between sovereign authorities. From 1313, the issuing of letters of marque became a purely royal prerogative,

78 Keen, Laws of War, p. 219.

79 Chavarot, "Lettres de marque," pp. 56-64, Olim, III, no. LXXXIX, pp. 342-345. 
as Philippe le Bel tended to control and discourage this recourse in order to avoid the escalation of conflicts which could prove detrimental to the kingdom's foreign policies. ${ }^{80}$

In England, reprisals between towns were prohibited in 1274, but the practice persisted at least in London. ${ }^{81}$ The English use of the term "marque" probably came from either France or Spain, perhaps through Gascony where reprisals were a time-honoured action in disputes. The English letters of marque in maritime affairs in the 129os seem to support this origin in Gascony, since the marque in the sources from this period was granted solely to Gascons. In some ways this seems to have been a desperate measure and proved detrimental to English foreign policy, as reprisals between Bayonnais and Castilians apparently got out of hand (see chapter 7$)^{82}$

Before commencing an analysis of the letters of marque, I will briefly clarify the meaning of marque in relation to reprisals and war. Auguste Dumas argued that there were several categories of rightful reprisal in the Middle Ages. First of all, Dumas, distinguished between prises in peacetime and during war.

In times of peace, the right of reprisal or marque was a right to take prises, either to avoid an imminent damage or threat or to obtain restitution for a damage already proven. Thus, if a ship was attacked, it had a right to defend itself and to capture the attacking ship if possible. For this, there was no need for any official authorisation. Reprisal and marque were:

the right, when one had been aggrieved by a foreigner, to take by force one's due or the equivalent of one's due from the fellow-citizens of this foreigner. From the fourteenth century, to have recourse to this action one had to be furnished with government authorisation: it was thus necessary to have obtained letters of marque or reprisals by one's prince before carrying out these actions. ${ }^{83}$

In wartime, one could legitimately take prises if it was from the subjects and allies of the enemy, and in civil war against the opposing party, or

80 Timbal, "Lettres de marque," p. 122, Chavarot, "Lettres de marque," pp. 63-64.

81 Gardiner, "Belligerent rights," p. 538, n. 39.

82 Rodger, Safeguard, p. 128.

83 "le droit, quand on avait été lésé par un étranger, de reprendre par la force son bien, ou l'équivalent de son bien, sur les concitoyens de cet étranger. Dès le XIVe siècle, pour y recourir, on devait s'être muni auparavant d'une autorisation de son gouvernement: il fallait avoir obtenu de son prince des lettres de marque ou de représailles." Dumas, Étude, pp. 3-4. 
against the enemies of one's particular allies even though one's ruler was not at war with the ally's enemy. The example given by Dumas for the latter was the French mariners' operations in the 1330 s to help the Scots against the English. ${ }^{84}$ This distinction between reprisal and war was also stressed by Mas Latrie, who sharply distinguished between privateering and reprisals. The right to privateering ("le droit de course") was the right that a sovereign could concede to his subjects to arm ships to attack the vessels of the enemy's merchants in times of open war. This right was different from the right to reprisals, which could only be accorded in times of peace to obtain individual restitution after a denial of justice by the other party. During the actions of reprisal, the aggrieved was only allowed to take goods from the foreign party up to the loss that he had suffered but no more than that, and he was not permitted to commit actions which would endanger the peace between the kingdoms. ${ }^{85}$ Nevertheless, while Mas Latrie and Dumas considered it a right, Chavarot asserts that it did not as such have a legal foundation until the sixteenth century and consequently should be considered an act (fait). ${ }^{86}$

The letter of marque in the Middle Ages was thus different to those commissions of the same name issued in the seventeenth and eighteenth centuries. The medieval letter of marque was purely a peace-time measure to be issued by the government to private persons for them to obtain restitution from the pirate or his countrymen up the sum lost. Later, however, with the advent of state armies where private persons acted as auxiliaries to the already existing navy, the letters of marque became a privateering commission. ${ }^{87}$

In the marque (as indeed in reprisals and arrests), three factors were stressed: it was a strictly peace-time measure; it was based on collective liability for the crimes of one's countrymen; and it was a quasi-legal measure to obtain restitution by private or public means when all acts of diplomacy had failed. While marque was related to retaliation, it was controlled and never led to war between the kingdoms, according to Chavarot $^{88}$ - even though other historians have pointed out that at the very

84 Dumas, Étude, pp. 3-4.

85 Mas Latrie, "Droit de marque," p. 531, see also Chavarot, "Lettres de marque," pp. 52-53, Timbal, "Lettres de marque," p. 111, Jal, Glossaire, p. 925.

86 Chavarot, "Lettres de marque," p. $5^{2}$.

87 Neff, War, p. 109, Thomson, Mercenaries, pp. 22-23.

88 Chavarot, "Lettres de marque," pp. 52-53, see also Timbal "Lettres de marque," p. 111, Jal, Glossaire, p. 925. 
least it posed a potential risk of war if the concession of marque was not controlled.

However, the problem with reprisal in general was that, as Timbal noted, it had to be controlled, in order that people with letters of marque did not abuse this "limited license" against specific targets for a specific amount to commit indiscriminate piracy. Furthermore, marque was a nuisance to the international trade, as one action of reprisal / marque was liable to be answered by a counter-marque, since most often the victim was innocent and therefore in turn considered himself entitled to a letter of marque. Thus, marque could set off a chain reaction of reprisals to the detriment of trade in general. Nevertheless, acts committed by holders of letters of marque were not piracy, but were legitimate due to the authority which had conceded them. In other words, it was legitimate but restrained piracy recognised by all kingdoms in Europe. ${ }^{89}$

How the governments imagined that this would work without recourse to violence is unspecified in the sources, but it must have been clear to all that an assault by a person with a letter of marque on an innocent fellow countryman of a pirate could not be seen by the victim as anything else but a pirate assault, and consequently this would lead to physical confrontation. In other words, gratuitous violence and general plunder were prohibited by the governments, as this constituted vengeance and unlicensed plunder. In reality, however, this proved extremely hard to control and nobody could be expected to hand over their goods voluntarily. Nonetheless, by prohibiting violence the government could wash its hands of future acts of violence. Thus, reprisals constituted a curious quasi-war between individuals, licensed but without the direct involvement of the government. The letter of marque is therefore the clearest and most institutionalised version of reprisals. From these rules, it is apparent that reprisal (in the form of arrest without violence) was admissible, but retaliation was not. However, when reprisals were carried out, they easily ended up taking the form of retaliation.

What we are dealing with in the government-authorised reprisal was a purely economic measure of recovery of property. Here no room was left for emotions like hatred or vindictiveness. The reason the authorities handled the suits thus was probably that they could be reduced to a mere question of property, and once a plaintiff had been granted restitution, the case was closed even though the plaintiff might still be harbouring

89 Timbal, "Lettres de marque," pp. 119-120. 
hatred against the pirates. While this certainly was a sensible approach to the problem when "police" forces were lacking, it could not be counted on to quell hostility completely. Nevertheless, we can say that the system of reprisals authorised by governments was based on a system of fair warning to avoid escalation of the disputes. However, it was intended more to protect the kings and their subjects than to assure justice for the individual, as shown in the case of Henry de Oreford.

Grossly stated, the execution of reprisal could be expressed in two ways. Either the kings ordered arrests of the goods of the pirate's compatriots in their ports up to the amount of the losses suffered, or a private remedy was given where the plaintiff was authorised by the king to seek justice via restitution by his own power over the pirate's compatriots at sea. Both of these were called marque, even though the letters of marque seem to refer to the authorisation of the private restitution, whereas arrest was carried out by governmental agents.

\section{The Bayonnais Letters of Marque}

It was often rather hard to be accorded a letter of marque, and it was not something that the rulers would issue easily. An example of such a denial occurred in $1305(?)$, when the owner of the goods in a Bayonnais vessel, Bidau Brane, complained to Edward I that his ship was plundered by people of Calais and Saint-Omer off the coast of Dover. These pirates had in turn sold the goods (linen and wine) to a Spanish vessel in Winchelsea. Brane now asked the king for a marque ("doner marke sur les vins") on the wines in the Spanish vessel so that by this marque (la marke) he could obtain recovery for his losses. He ended the request by stating that the piracy happened in a time of peace between England and France ("temps de la sufferance"). Edward I replied that for certain reasons (perhaps the ongoing negotiations with the Castilians or the negotiations with the French over the killing at Quéménès), he would not grant him a marque (la marke) but that he would be willing to grant a letter of request. ${ }^{90}$ The marque in question here must be an arrest of the goods of the Spanish merchant purchased from the French and not a licence to undertake a private attack on the French to obtain restitution. The manoeuvre here

90 TNA SC 8/84/4185, Champollion, I, 368-69, assumes this took place around 1290, but the English National Archives more prudently date this to 1305 , since a letter of protection presumable was given to Bidau on 6 April 1305. $R G$, III, no. 4917, p. 488. 
was essentially to pass the buck of restitution to the Spanish who had bought the wine from the French in good faith (?).

The first proper marque case in the Anglo-Gascon sources concerns a grant of a letter of marque to Jean de Lévignacq (Vinhiaco, Daubinhac), Guillaume Arnaud de Bielle (Viele) and Laurent de Piru. These were merchants, mariners and citizens of Bayonne. In this letter, dated 4 June 1293, Edward I let all his officers know that the three had obtained a letter of marque (licenciam marchandi) against the subjects of the king of Castile up to the value of their losses. The reason for the granting of the marque was that their ships had been plundered of goods to the value of £20oo sterling by Castilians under the orders of King Sancho IV of Castile. This was not an isolated incident, but rather the pinnacle of a series of piracies, killings, imprisonments, plunders and tortures committed by Castilians against the Bayonnais. Therefore, Edward I ordered his officers not to hinder but to aid these Bayonnais in any way in carrying out their marque up to the value of their losses, but he reminded them that the marque was only valid for two years. ${ }^{91}$ In 1296, Jean de Lévignacq petitioned for a renewal of the letter of marque (litteram marchandi) against the Spanish as well as the Portuguese, since he still had not obtained restitution. Edward replied to his lieutenant in Gascony, Edmund of Lancaster, that this request should be refused if peace with Castile was restored. If, however, peace was not concluded, Edmund was to grant the letter and help Lévignacq in any way possible in obtaining restitution for his losses from the Spanish and the Portuguese. ${ }^{92}$

Another example is the granting of a letter of marque (licenciam \& licentiam marcandi) to Bernard Dongressilli, merchant and citizen of Bayonne, against the Portuguese in 1295. Bernard had gone to Africa to buy figs and grapes destined for England. While the ship was anchored off the port of Lascoss (Cascaes or Lagos) in Portugal, in shelter from bad weather, it was attacked by pirates from Lisbon. They plundered the ship and carried the goods to Lisbon, where the king of Portugal allegedly received onetenth of the spoils. Bernard suffered losses to the amount of $£ 700$ sterling and requested a letter of marque against the Portuguese on sea as well as on land. Through the mayor and the municipal government of Bayonne, Edward granted a letter of marque to Bernard, his heirs and successors to make reprisals ("possit marchare, retinere et sibi appropriare illa") on the

$91 E M D P$, I, no. 218, p. 382, $R G$, III, no. 2132, pp. $75^{-76}$.

$92 E M D P$, I, no. 219, pp. 382-383, $R G$, III, no. 4254, pp. 340-341. 
Portuguese, and especially those of Lisbon in the English king's lands as well as outside them, until Bernard had received satisfaction for his losses plus the expenses incurred by him in this undertaking. The duration of this marque was for five years or until it pleased the king. Therefore, the king ordered all his officers to help Bernard in obtaining satisfaction. However, the king stressed that Bernard was only allowed to take up to the lost values, the rest he had to answer for. ${ }^{93}$

An interesting document from 1317 lucidly points out the problems with marque and why the kings were reluctant to grant it. On 6 June that year, the mayor and jurati of Bayonne wrote to Edward II complaining that he had granted letters of marque (marcham) to Johannes de Bainhers and Arnaud de Saint-Martin against the Spanish. Apparently, this had caused Lady Maria of Biscaya to complain and ask Edward not to include the Biscayans in these acts of reprisals. The initial complaint from Maria was issued sometime in 1317 . She asked Edward II to specify that the marque (marches, gage) pronounced against Castilians were not extended to the Biscayans, who were nominally under Castile but enjoyed semiindependence from the Crown. Furthermore, they had been neutral in the conflict between Bayonne and Santander, Laredo and Castro Urdiales, and during the Gascon War they had aided the English. Probably some time later, on 12 April 1317, King Alfonso XI of Castile wrote to Edward on behalf of his uncle, Lord Johannes of Biscay, whose towns Bermeo, Bilbao, Placencia and Lequeitio, had suffered seizure of their goods in Bordeaux by the hands of the seneschal. Alfonso asked that they were not to be held responsible for crimes done by other Castilian subjects and asked that they would be exempt from arrest. ${ }^{94}$ The Bayonnais, for their part, complained that the Biscayans were the friends of Bayonne and that Johannes and Arnaud were not Bayonnais citizens at all. ${ }^{95}$ The Biscayans therefore had had no part in Bayonne's maritime war with Santander, Laredo and Castro Urdiales, but had remained at peace with Bayonne. Johannes and Arnaud should thus not be allowed to drag the town into a conflict and sour relations with the Biscayans. The Bayonnais therefore asked Edward to revoke the marque (marchas). Furthermore, Johannes apparently had taken goods from Flemings in Bordeaux under the pretext of a

\footnotetext{
93 RG, III, no. 3892, pp. 292-94, Foedera 1273-1307, p. 828, Champollion, I, 418-20, Marsden, Law and Custom, pp. 38-40.

94 Foedera 1307-1327, p. 325.

95 "Qui Johannes \& Arnaldus non sunt vicini nostri Baion", ymo sunt totaliter extra partes, \& a nostrâ viciniâ alieni', Foedera 1307-1327, p. 332.
} 
reprisal (marchati), on account of a claimed Flemish arrest of Bayonnais goods in Flanders. Thus, by his "rogue" actions, Johannes was endangering the relationship between Bayonne and the Flemings. Therefore, the Bayonnais asked Edward to remunerate the victims of these two, so that Bayonne could trade in peace. ${ }^{96}$ However, it is doubtful if these two persons were not in fact citizens of Bayonne after all. Arnaud de Saint-Martin certainly had been a citizen of Bayonne as late as in 1316, and he had a long history of quarrels with the Castilians originating in the 1290s, when he and other Bayonnais merchants were unable to obtain restitution for goods plundered by the Castilians. While Arnaud had received partial restitution by an arrest of Spanish ships by the royal officers in Dover and in Portsmouth in 1316, he was still lacking of 165 marcs and 20 deniers. Edward therefore ordered the seneschal of Gascony to arrest Spanish goods to this sum. ${ }^{97}$ It is possible that Johannes and Arnaud had lost their citizenship, but it is equally likely that the Bayonnais government repudiated them in order to avoid conflict. While it may be that Johannes was abusing his marque for indiscriminate piracy and fraudulent reprisals, at least Arnaud de Saint-Martin had good reason for doing it. In any case, in 1315 and 1316, the Bayonnais mariners were embroiled in struggles with Flemish mariners. The actions of "rogues" like the above-mentioned were probably detrimental to the interests of the government in Bayonne, who, with the ongoing reforms of the Societas Navium, were tightening the municipal control over the shipmasters and mariners.

It is quite interesting that the letters of marque that we know of from the first three decades of the fourteenth century were primarily granted to Bayonnais. An explanation for this may have been the rarity of Castilian merchants going to Bayonne to trade, as argued by Goyheneche. Instead,

\footnotetext{
${ }^{96}$ Foedera 1307-1327, p. 332.

97 Arnaud de Saint-Martin is a somewhat nebulous character. In 1305, he was clearly a citizen and merchant of Bayonne, complaining with other Bayonnais of Spanish piracies and obtaining a marque against them (TNA SC 8/388/E1229). In 1308, he was called citizen of Bayonne in a document in the negotiations of settlement with Castile (Foedera 13071327 , p. 44), but the next time the name appears in the sources in 1313 he was implicated in Edward II's prohibitions of tournaments in England. Here, he is called serviens ad arma of the king (Foedera 1307-1327, p. 196, 228). In November 1313, one Arnaud de Saint Martin was pardoned for the death (killing?) of Arnaud de Faure of Bonnegarde ( $R G$, IV, no. 1151, p. 318), but the citizen and merchant of Bayonne, Arnaud de Saint Martin resurfaces again in the cases of unsettled restitution with the Castilians in 1315 and 1316 (Foedera 1307-1327, pp. 268 and 290-291), before he is finally mentioned with Johannes de Bainhers. It may be that Arnaud de Saint-Martin at one point was a royal sergeant, but it equally might be that we are in fact dealing with two different persons called Arnaud de Saint-Martin, a merchant and a sergeant-at-arms.
} 
these Castilian merchants generally met the Bayonnais in ports such as Bordeaux, La Rochelle, on the coast of Brittany and in Flanders. ${ }^{98}$ However, since these towns were not involved in the struggle and the English king held no power there (except for Bordeaux), arrest by the usual means would be impossible. Thus, the Bayonnais were obliged to seek the restitution at sea and by their own private power, rather than relying on royal or municipal arrest.

While the kings tried to control reprisals, in the end their initiatives do not seem to have hindered private reprisals. Merchants sometimes seemed reluctant to plead to the king and courts their case for restitution, not least because arrest could take years to effect and even then no positive result was guaranteed. Thus, sometimes the merchants and mariners preferred to take matters into their own hands and gain immediate restitution and restoration of honour at the possible expense of their compatriots. Likewise, if enmity had festered for a long time and sleights of honour (real or imagined) were involved, the mariners and merchants seem to have been likely to retaliate. Sometimes this, too, must have served as an excuse for outright piracy. In other words, the judicial system and the inherent problems of resolving questions of violence and robbery committed at sea led to or sometimes forced the aggrieved to handle matters themselves to obtain restitution. A final example illustrates the indifference to or inability of the princes in dealing with their subjects' piracies. In a reply from the count of Hainault, Holland and Zeeland in 1324 to Edward II as part of a correspondence over piracy against English merchants, the count wrote that even though he knew the Zeelanders had falsely claimed that their piracies were licensed by the count, Edward had to understand that many of his subjects from Zeeland had been robbed by English mariners and that his men could not refrain from recovering their goods by the only possible way, reprisals, since Edward had refused to do restitution. ${ }^{99}$ Thus, these reprisals were in essence personal and private wars waged by an individual against a community, with or without royal license and support.

In the end, it seems impossible to distinguish piracy from reprisals. Mariners rarely, if ever, would admit to having committed a maritime plunder based purely on opportunism and greed, since this would indeed be an admittance of robbery which was punished severely in the Middle

98 Goyheneche, Bayonne, pp. 350-363.

99 CCR 1323-1327, p. 171. 
Ages (see chapter 8). Thus, while opportunistic piracy arguably did occur, it was only possible to define it as such after the authorities had proclaimed a judgement in the case. However, in the complaints it is an indisputable fact that victims of reprisals claimed to be victims of piracy. 